\title{
Correction: Cost-effectiveness of clubfoot treatment in low and middle income countries by the Ponseti method
}

Grimes CE, Holmer H, Maraka J, et al. Cost-effectiveness of club-foot treatment in low-income and middle-income countries by the Ponseti method. BMJ Glob Health 2016;1:e000023. doi: 10.1136/bmjgh-2015-000023

Author would like to highlight below important errors pertaining to tables and text: 1. Table 1 on page 3 , the total cost of supplies, unilateral should be 90 , and the total cost of supplies, bilateral should be 119 (please note that the sum total was not affected)

2. The first sentence in the results says that the average cost was 140 USD when it should be 167 USD (this is also the number cited in the table and abstract).

3 . The table on page four should read Ponseti treatment for congenital talipes equinovarus (average, Africa): 22.46 (5.28-29.75), not 18.92 (7.45-29.75)

Open access This is an Open access article distributed in accordance with the Creative Commons Attribution Non Commercial (CC BY-NC 4.0) license, which permits others to distribute, remix, adapt, build upon this work non-commercially, and license their derivative works on different terms, provided the original work is properly cited, appropriate credit is given, any changes made indicated, and the use is non-commercial. See: http://creativecommons.org/licenses/by-nc/4.0/.

C Author(s) (or their employer(s)) 2018. Re-use permitted under CC BY-NC. No commercial re-use. See rights and permissions. Published by BMJ.

BMJ Glob Health 2018;3:e000023corr1. doi:10.1136/bmjgh-2015-000023corr1 